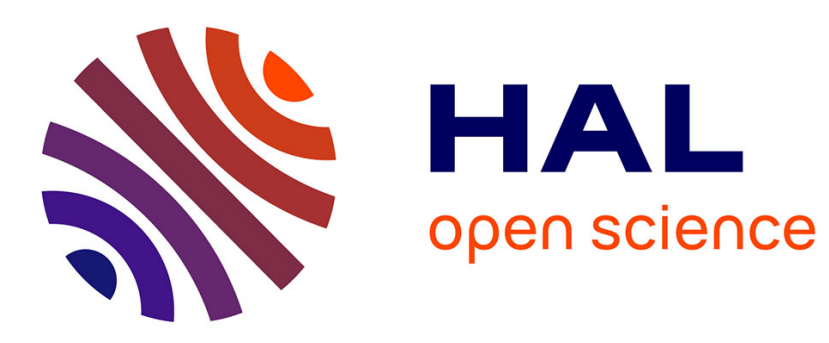

\title{
Acquired erythropoietic protoporphyria
}

\author{
Daniel Blagojevic, Thomas Schenk, Oskar Haas, Brigitte Zierhofer, \\ Christophoros Konnaris, Franz Trautinger
}

\section{To cite this version:}

Daniel Blagojevic, Thomas Schenk, Oskar Haas, Brigitte Zierhofer, Christophoros Konnaris, et al.. Acquired erythropoietic protoporphyria. Annals of Hematology, 2009, 89 (7), pp.743-744. 10.1007/s00277-009-0859-7 . hal-00535103

\section{HAL Id: hal-00535103 \\ https://hal.science/hal-00535103}

Submitted on 11 Nov 2010

HAL is a multi-disciplinary open access archive for the deposit and dissemination of scientific research documents, whether they are published or not. The documents may come from teaching and research institutions in France or abroad, or from public or private research centers.
L'archive ouverte pluridisciplinaire HAL, est destinée au dépôt et à la diffusion de documents scientifiques de niveau recherche, publiés ou non, émanant des établissements d'enseignement et de recherche français ou étrangers, des laboratoires publics ou privés. 


\title{
Acquired erythropoietic protoporphyria
}

\author{
Daniel Blagojevic • Thomas Schenk • Oskar Haas • \\ Brigitte Zierhofer • Christophoros Konnaris • \\ Franz Trautinger
}

Received: 16 October 2009 /Accepted: 21 October 2009/Published online: 10 November 2009

(C) Springer-Verlag 2009

\begin{abstract}
Dear Editor,
Porphyrias are a group of diseases characterized by aberrations in the heme biosynthetic pathway. They can be classified according to the primary site of the enzymatic defect (i.e., hepatic versus erythropoietic) or according to their clinical presentation into acute versus chronic or noncutaneous versus cutaneous forms. Among the cutaneous porphyrias, erythropoietic protoporphyria (EPP) stands out as the only form characterized by an immediate painful reaction to sunlight [1].

We report a case of an acquired variant of EPP developing in a patient with myelodysplastic syndrome
\end{abstract}

\author{
D. Blagojevic $\cdot$ B. Zierhofer $\cdot$ F. Trautinger \\ Karl Landsteiner Institute for Dermatological Research, \\ Landesklinikum St. Poelten, \\ St. Poelten, Austria \\ T. Schenk \\ Department of Internal Medicine I, Landesklinikum St. Poelten, \\ St. Poelten, Austria \\ O. Haas \\ Ambulatorium Medgen, \\ Vienna, Austria \\ C. Konnaris \\ Department of Gynecology and Obstetrics, \\ Medical University of Vienna, \\ Vienna, Austria \\ D. Blagojevic $(\square)$ \\ Department of Dermatology and Venereology, \\ Landesklinikum St. Poelten, \\ Propst Fuehrer Str. 4, \\ 3100 St. Poelten, Austria \\ e-mail: daniel.blagojevic@stpoelten.lknoe.at
}

most likely due to the genetic instability associated with the disease.

A 66-year-old Caucasian man presented for the evaluation of stinging-burning pain that developed immediately after exposure to sunlight and was restricted to the exposed skin. The condition had started 4 years earlier and had become so severe that the patient avoided direct sunlight completely. Densely woven fabrics but not sunscreens or window glass provided protection. On physical examination, we found mild, waxy thickening with small, scar-like depressions of the skin over the nose and the backs of the hands. The patient had been evaluated earlier for polymorphic light eruption, solar urticaria, and lupus erythematosus without positive results. The patient's history was remarkable for a myelodysplastic syndrome (myelodysplastic syndrome-refractory anemia with ringed sideroblasts) that had been diagnosed 4 years earlier at about the same time when the skin symptoms had appeared. Anemia was the leading symptom of the myelodysplastic syndrome and was treated with repeated erythrocyte substitution. Examination of native blood and bone marrow smears revealed autofluorescence of a large proportion of the patient's red blood cells (Fig. 1). Biochemical analysis showed increased levels of free erythrocyte protoporphyrin $(241 \mu \mathrm{g} / \mathrm{dl}$ red blood cells, normal range $<120 \mu \mathrm{g} / \mathrm{dl})$, with normal levels of urinary porphyrins. The rest of the routine laboratory analysis was unremarkable except for anemia (hematocrit 33.1\%). Sequencing of DNA from the patient's bone marrow revealed heterozygosity for two predisposing alleles (IVS3-48 T > C, $252 \mathrm{~A}>\mathrm{G}$ ) in the ferrochelatase gene together with a so far undescribed polymorphism (IVS2 + $169 \mathrm{G}>\mathrm{A}$ ) in intron 2 [2, 3]. Larger deletions were excluded by fluorescence in situ hybridization analysis. A diagnosis of acquired EPP was made and 

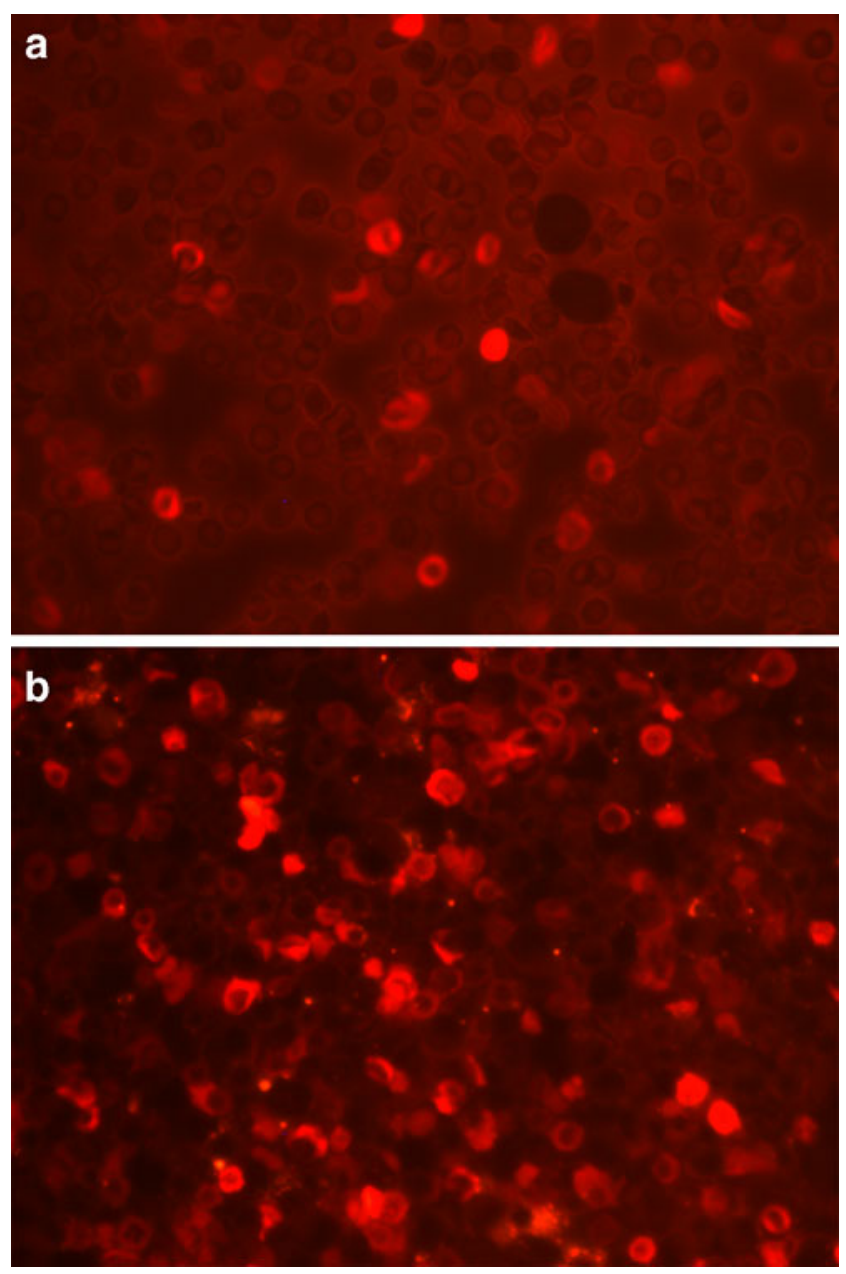

Fig. 1 Erythrocyte autofluorescence in a smear of freshly obtained bone marrow aspirate (a) and a freshly obtained blood smear (b)

treatment with oral beta-carotene (200 $\mathrm{mg}$ daily) was begun. Within 2 months, the patient's sensitivity to sunlight had significantly improved and remained stable even upon tapering of the dose.

EPP (MIM 177000) is an inherited disorder caused by deficiency of ferrochelatase causing accumulation of free protoporphyrin in the erythron, associated with a painful skin photosensitivity commencing in childhood. Deposition of protoporphyrin in the liver causes liver damage in rare cases. Autofluorescence of a large proportion of red blood cells can be observed by fluorescence microscopy. The mode of inheritance in EPP is autosomal dominant in most cases [4].

Acquired variants of EPP have been rarely described and are almost exclusively associated with myelodysplastic or myeloproliferative syndromes. Such patients may either have a somatic mutation in the ferrochelatase gene or a deletion of one ferrochelatase allele in hematopoietic cells, with clonal expansion as part of the myelodysplastic process [5].

EPP should always be considered when adverse reactions to sunlight occur without delay and already after brief exposures. Although usually congenital and hereditary with symptomatic presentation in early childhood, acquired cases due to somatic ferrochelatase gene mutations rarely occur. Thorough anamnesis and accurate interpretation of the patient's history will unfailingly lead to the correct diagnosis.

\section{References}

1. Bickers DR, Frank J (2008) The porphyrias. In: Wolff K, Goldsmith LA, Katz SI, Gilchrest BA, Paller AS, Leffell DJ (eds) Dermatology in general medicine. McGraw-Hill, New York, pp $1228-1256$

2. Di Pierro E, Cappellini MD, Mazzucchelli R, Moriondo V, Mologni D, Zanone Poma B et al (2005) A point mutation affecting an SP1 binding site in the promoter of the ferrochelatase gene impairs gene transcription and causes erythropoietic protoporphyria. Exp Hematol 33:584-591

3. Aplin C, Whatley SD, Thompson P (2001) Late-onset erythropoietic porphyria caused by a chromosome $18 \mathrm{q}$ deletion in erythroid cells. J Invest Dermatol 117:1647-1649

4. Rüfenacht UB, Gouya L, Schneider-Yin X, Puy H, Schäfer BW, Aquaron R et al (1998) Systematic analysis of molecular defects in the ferrochelatase gene from patients with erythropoietic protoporphyria. Am J Hum Genet 62:1341-1352

5. Bottomley SS, Muller-Eberhard U (1988) Pathophysiology of heme synthesis. Semin Hematol 25:282-302 